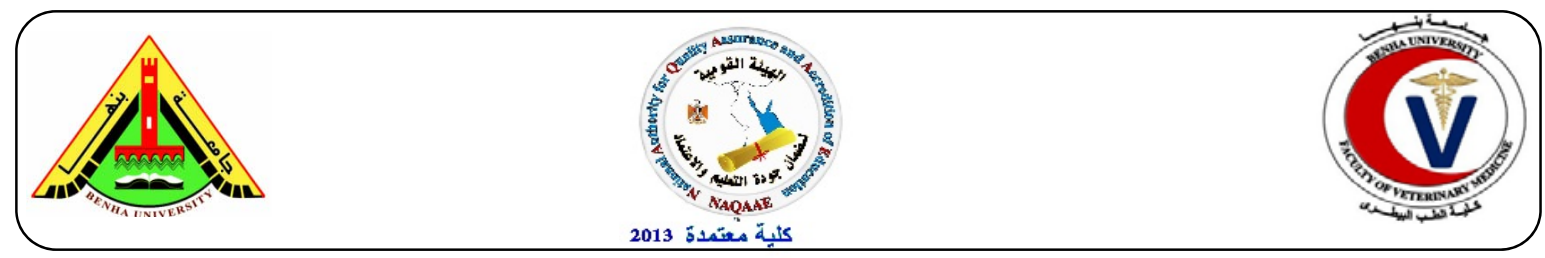

\title{
Detection of some heavy metals in fish (Tilapia nilotica and Clarias lazera) at Menofia governorate
}

\author{
Shaltout A. Fahim ${ }^{1}$, Hashim F. Mohammed ${ }^{2}$, El-nahas-Saber \\ ${ }^{1}$ Department of food control (meat hygiene). Fac. Vet. Med., Benha. ${ }^{2}$ Food Hygiene, Animal Health \\ Research Institute, Dokki branch.
}

\begin{abstract}
A B S T R A C T
A grand total of eighty random samples of Tilapia nilotica and Clarias lazera (40 of each) were collected after catching in Shebin El-kom, Menofia Governorate. The samples were directly transferred to the laboratory for determination of their contents of mercury, lead and cadmium. The evaluation revealed that the mean values of mercury concentration $(\mathrm{mg} / \mathrm{kg})$ in the examined fresh water fish were $0.46 \pm 0.03 \mathrm{mg} / \mathrm{kg}$ for Tilapia nilotica and $0.52 \pm 0.04 \mathrm{mg} / \mathrm{kg}$ for Clarias lazera. Furthermore, the mean values of lead concentration $(\mathrm{mg} / \mathrm{kg})$ in the examined samples of Tilapia nilotica and Clarias lazera were $0.08 \pm 0.02$ and $0.14 \pm 0.02 \mathrm{mg} / \mathrm{kg}$, respectively. In addition, the mean values of cadmium concentration in the examined samples of fresh water fish were $0.10 \pm 0.01 \mathrm{mg} / \mathrm{kg}$ for Tilapia nilotica and $0.14 \pm 0.02 \mathrm{mg} / \mathrm{kg}$ for Clarias lazera. The public health importance of such heavy metal residues were discussed.
\end{abstract}

Key words: Atomic Absorption Spectrophotometer, heavy metals, contamination.

$$
\text { (http://www.bvmj.bu.edu.eg) }
$$

(BVMJ-29(1): 124-128, 2015)

\section{INTRODUCTION}

$\mathrm{F}$ ish occupy one of the foremost places among the food products of animal origin in nutritive value that attributed to their contents of high biological valuable proteins, lipids, vitamins and essential fatty acids as well as several kinds of minerals (Metin et al., 2000 and Darwish et al., 2003). Heavy metals are natural constituents of earth's crust and they also defined as electropositive elements having density greater five times than that of water. Heavy metals are dangerous because they tend to bioaccumulate (Smith, 1992). Today, the environmental pollution by heavy metals is considered as one of the most serious problems in the world over the last few decades. Emissions of heavy metals to the environment occur via a wide range of pathways, including air, water, and soil (Jarup, 2003). Lead is recognized as a toxic substance, which accumulates in the body due to its low rate of elimination. The classic symptoms of lead poisoning are colic, abdominal pain, anemia and encephalopathy. As well as, lead is considered as one of immunosuppressive agents in human (Chisolm, 1973). On the other hand, lead causes renal tubular dysfunction indicated by proteinuria or aminoaciduria in humans, also, lead inhibits heme synthesis resulting in fragile cell wall of red blood cells leading to anemia (Jones and Hunt, 1983). Cadmium is classified as a probable human carcinogen. Chronic exposure to cadmium is associated with a wide range of diseases, including heart diseases, anemia, skeletal weakening, depressed immune system response, kidney and liver diseases (Codex Alimentarius , 2001). Cadmium had a significant role in the incidence of chronic renal failure (Friberg 1984). Mercury compounds are highly toxic, because they are fat soluble and easily absorbed and accumulated in erythrocytes and CNS (Castoldi et al., 2003). Mercury poisoning causes redness 
of lips, throat and tongue, loss of teeth, swelling and redness of skin with pink red finger tips. It affects the nervous system causing irritability (Mert , 1987). This work was carried out to estimate the levels of mercury, lead and cadmium residues in the muscular tissues of some Nile fresh water fish such as Tilapia nilotica, Clarias lazera as well as comparing of such residues with the safe permissible limits stipulated by Egyptian Organization for Standardization (E.O.S. 2005) .

\section{Material and Methods:}

\subsection{Collection of Samples:}

A grand total of 80 random samples of Tilapia nilotica and Clarias lazera (40 of each) were collected from different fish market at Menoufia Governorate. The collected samples were directly transferred to the laboratory for determination of their contents of lead, cadmium and mercury.

\subsection{Preparation of samples:}

The fish samples were washed with tap water to remove slime and mud then fish muscles were taken after removal of scales and fins and transmitted to sterile blender jar to be homogenized .

\subsection{Determination of heavy metals}

\subsubsection{Washing procedure: The trials} recommended by Shibamoto and Bjeldanes (1993).

\subsubsection{Digestion procedures: according to} (Finery et al., 1990).

A. Preparation of samples for estimation of cadmium, lead, mercury. B. Preparation of blank and standard solution.

\subsection{Determination and Analysis :}

By using Atomic Absorption Spectrophotometer, which was adjusted at $217.0 \mathrm{~nm}$ for lead, $228.8 \mathrm{~nm}$ for cadmium and $253.7 \mathrm{~nm}$ for mercury.

\subsection{Quantitative determination of heavy metals :}

Examined samples were calculated as $\mathrm{mg} / \mathrm{kg}$ on wet weight according to the following equation: $C=R \times(D / W)$. Where, $\mathrm{C}=$ Concentrations of element $(\mathrm{mg} / \mathrm{kg})$ wet weight, $\mathrm{R}=$ reading of digital scale of AAS, $\mathrm{D}=$ Dilution of prepared sample, $\mathrm{W}=$ Weight of the sample.

\section{RESULTS}

Results achieved in (Table 1) revealed that the mean values of mercury concentration $(\mathrm{mg} / \mathrm{kg})$ in examined samples were $0.46 \pm$ $0.03 \mathrm{mg} / \mathrm{kg}$ for Tilapia nilotica and $0.52 \pm$ $0.04 \mathrm{mg} / \mathrm{kg}$ for Clarias lazera. Further more , $32.5 \%$ and $37.5 \%$ of the examined samples of Tilapia nilotica and Clarias lazera exceeded the maximum permissible limit of mercury $(0.5 \mathrm{mg} / \mathrm{kg})$, respectively according to E.O.S (2005) ( Table 2). Results recorded in Table (3) showed that the mean values of lead concentration $(\mathrm{mg} / \mathrm{kg})$, Tilapia nilotica and Clarias lazera were $0.08 \pm 0.02$ and $0.14 \pm 0.02 \mathrm{mg} / \mathrm{kg}$, respectively. According to the safe permissible limit stipulated by (EOS, 2005), $25 \%$ and $50 \%$ of the examined samples Tilapia nilotica and Clarias lazera were unacceptable table (4). The mean values of cadmium concentration in the examined samples were $0.10 \pm 0.01 \mathrm{mg} / \mathrm{kg}$ for Tilapia nilotica and $0.14 \pm 0.02 \mathrm{mg} / \mathrm{kg}$ for Clarias lazera as shown in table (5). Moreover, $40 \%$ and $50 \%$ of the examined samples of Tilapia nilotica and Clarias lazera were unfit for human consumption based on their contents of cadmium, which exceeded the maximum permissible limit $(0.05 \mathrm{mg} / \mathrm{kg})$ according to E.O.S. (2005) in table (6).

Table (1): Statistical analytical results of mercury concentrations $(\mathrm{mg} / \mathrm{kg})$ in the examined samples of fresh water fish $(n=40)$.

\begin{tabular}{lccc}
\hline Fish species & Min. & Max. & $\begin{array}{c}\text { Mean } \pm \\
\text { S.E* }\end{array}$ \\
\hline $\begin{array}{l}\text { Tilapia } \\
\text { nilotica }\end{array}$ & 0.10 & 1.20 & $0.46 \pm 0.03$ \\
Clarias lazera & 0.15 & 1.30 & $0.52 \pm 0.04$ \\
\hline
\end{tabular}


Table (2): Acceptability of the examined samples of fresh water fish based on their contents of mercury $(n=40)$.

\begin{tabular}{|c|c|c|c|}
\hline \multirow{2}{*}{$\begin{array}{c}\text { Fish } \\
\text { species }\end{array}$} & \multirow{2}{*}{$\begin{array}{c}\text { Permissible } \\
\text { Limit } \\
(\mathrm{mg} / \mathrm{kg})\end{array}$} & \multicolumn{2}{|c|}{$\begin{array}{c}\text { Unaccepted } \\
\text { Samples }\end{array}$} \\
\hline & & No. & $\%$ \\
\hline $\begin{array}{l}\text { Tilapia } \\
\text { nilotica }\end{array}$ & 0.5 & 13 & 32.5 \\
\hline $\begin{array}{c}\text { Clarias } \\
\text { lazera }\end{array}$ & 0.5 & 15 & 37.5 \\
\hline
\end{tabular}

*According to "E.O.S"(2005)

Table (3): Statistical analytical results of lead concentrations $(\mathrm{mg} / \mathrm{kg})$ in the examined samples of fresh water fish $(n=40)$.

\begin{tabular}{lccc}
\hline Fish species & Min. & Max. & $\begin{array}{c}\text { Mean } \pm \\
\text { S.E* }\end{array}$ \\
\hline $\begin{array}{l}\text { Tilapia } \\
\text { nilotica }\end{array}$ & 0.01 & 0.25 & $0.08 \pm 0.02$ \\
Clarias lazera & 0.03 & 0.35 & $0.14 \pm 0.02$ \\
\hline
\end{tabular}

Table (4): Acceptability of the examined samples of fresh water fish based on their contents of lead $(n=40)$.

\begin{tabular}{cccc}
\hline \multirow{2}{*}{ Fish } & \multirow{2}{*}{$\begin{array}{c}\text { Permissible } \\
\text { Limit * } \\
\text { species }\end{array}$} & \multicolumn{2}{c}{ Unaccepted } \\
& $(\mathrm{mg} / \mathrm{kg})$ & No. & $\%$ \\
\hline $\begin{array}{l}\text { Tilapia } \\
\text { nilotica }\end{array}$ & 0.1 & 10 & 25 \\
$\begin{array}{l}\text { Clarias } \\
\text { lazera }\end{array}$ & 0.1 & 20 & 50 \\
\hline *According to "E.O.S"(2005) & &
\end{tabular}

Table (5): Statistical analytical results of cadmium concentrations $(\mathrm{mg} / \mathrm{kg}$ ) in the examined samples of fresh water fish $(n=40)$.

\begin{tabular}{lccc}
\hline Fish species & Min. & Max. & $\begin{array}{c}\text { Mean } \pm \\
\text { S.E* }\end{array}$ \\
\hline $\begin{array}{l}\text { Tilapia } \\
\text { nilotica }\end{array}$ & 0.02 & 0.28 & $0.10 \pm 0.01$ \\
Clarias lazera & 0.02 & 0.30 & $0.14 \pm 0.02$ \\
\hline
\end{tabular}

Table (6): Acceptability of the examined samples of fresh water fish based on their contents of cadmium $(n=40)$.

\begin{tabular}{cccc}
\hline \multirow{2}{*}{$\begin{array}{c}\text { Fish } \\
\text { species }\end{array}$} & \multicolumn{2}{c}{ Permissible } & \multicolumn{2}{c}{ Unaccepted } \\
Limit & \multicolumn{2}{c}{ Samples } \\
Tilapia & 0.05 & 16 & 40 \\
nilotica & & No & $\%$ \\
$\begin{array}{c}\text { Clarias } \\
\text { lazera }\end{array}$ & 0.05 & 20 & 50 \\
*According to "E.O.S"(2005) & & \\
\end{tabular}

\section{DISCUSSION}

Heavy metals are chemical elements, which cannot be destroyed or broken down through heat treatment or environmental degradation. Their persistence induced a variety of human health hazards as lethal, sublethal, acute and chronic toxicity (Levensen and Barnard, 1988).

The obtained results in the present study concluded that the examined samples of Clarias lazera contained higher mercury, lead and cadmium levels than those of Tilapia nilotica. The recorded results of mercury level in Table (1) were lower than those obtained by Sohsah- Madiha (2009) $(0.49 \pm 0.05$ for small size Tilapia nilotica , $0.81 \pm 0.05$ for large one, while in Clarias lazera were $0.72 \pm 0.04,0.98 \pm 0.08$ for small and large size, respectively). While, lower resuts were recorded by El-Zahaby- Dina (2007) $(0.013 \pm 0.001 \mathrm{ppm}$ in Tilapia nilotica, $0.040 \pm 0.001 \mathrm{ppm}$ in Claries lazera). Mercury occurs naturally in the environment in low level, the main source of mercury comes from industrial sources (Clarkson, 2002). Methyl mercury is more dangerous to human health than inorganic one because it cannot be excreted. In addition, it acts as accumulative poison and can cross blood -brain barrier to nervous tissue producing progressive and irreversible brain damage (Clark, 1989). Regarding to lead level, higher results were obtained by Sohsah - Madiha (2009) , 0.15 $\pm 0.02 \mathrm{mg} / \mathrm{kg}$ for small size Clarias lazera and $0.27 \pm 0.04 \mathrm{mg} / \mathrm{kg}$ for large size one, $0.11 \pm 0.01 \mathrm{mg} / \mathrm{kg}$ for small size Tilapia 
nilotica and $0.16 \pm 0.03 \mathrm{mg} / \mathrm{kg}$ for large size one. Lead is one of the earliest heavy metals used by human in all forms and considered as one of the most toxic metals because of its cumulative effect as well as severe toxic effects (Ibels and Pollock, 1986). Lead adversely affects CNS resulting in psychopathological symptoms including restlessness, dullness, irritability and memory loss. Ataxia, headache and muscular tremor might also occur (Manahan, 1992). The obtained resuts of cadmium levels in Table (5) were higher than those reported by Sohsah- Madiha (2009) , $0.11 \pm 0.01 \mathrm{mg} / \mathrm{kg}$ for small size Clarias lazera, but lower results for large size one $0.20 \pm 0.03 \mathrm{mg} / \mathrm{kg}$. While in Tilapia nilotica lower results $0.08 \pm 0.01$ $\mathrm{mg} / \mathrm{kg}$ for small size fish and higher result for large size one $0.12 \pm 0.02 \mathrm{mg} / \mathrm{kg}$. Cadmium is toxic element, which may induce nausea, insomnia, prostate cancer, testicular atrophy and kidney failure (Kikuchi et al., 2002). Cadmium is a heavy metal that accumulates in the body, and its accumulation in the brain damages both neurons and glial cells. Cadmium induced a stroglial toxicity and a stroglial death via glutathione depletion (Im et al., 2006). Generally, fish have the ability to concentrate heavy metals in their tissues in concentrations higher than those in water. So that fish is considered as a biological indicator for river pollution. Fish can bioaccumulate cadmium and mercury dissolved in water, but they cannot bioaccumulate lead in their tissues (Levensen and Barnard, 1988). The preventive measures intended to minimize the residue of heavy metal in water and fish include protection of Nile River. Education of public for environmental problems. Application of HACCP program during processing and handling storage and disposal of hazardous chemicals. Education of fish handlers and consumers with food pollution, their sources, health hazards and control through educational training programs. Catching of fish by using pesticides should be avoided.

\section{REFERENCES}

Castoldi, A. F., Coccini, T. and Manzo, L. 2003. Neurotoxic and molecular effects of methyl mercury in humans. Reviews on Environmental Health, 18:19 - 31 .

Chisolm, J. 1973. Management of increased lead absorption and lead poisoning. Eng. J. Med., 289:1016 1017.

Clark, R.B. 1989 Marine pollution, Oxford Science publications, $2^{\text {nd }}$ Ed. Clarendon press. Oxford. Chap. 5, pp. $130-140$.

Clarkson, T.W. 2002. The three modern faces of mercury. Environmental Health Prespect, 110(1):11-32.

Codex Alimentarius Commission Procedural Manual 2001 Maximum residual limits (MRLs) for pesticides. CAC / MRL, Rev. 1-2001.

Darwish, A.M., El-Mossalami, M.K., ElBassuony, R.A. 2003 Quality assurance of some fatty fishes. Assuit Vet. M. J. 49(98):79 - 96.

Egyptian Organization for Standardization and Quality Control, "E .O .S" 2005. Maximum residues limits for heavy metal in food. Ministry of Industry No. 2360/2005. Cairo, Egypt.

El-Zahaby-Dina, I.M. 2007. Microbiological and chemical studies on some fish and fish products in Menoufia Governorate. M.V.Sc., Thesis. (Meat Hygiene), Fac. Vet. Med., Menoufia Univ., Sadat Branch, Egypt.

Finery, M.W., Madden J.D., Feagly S.E., Grodner R.M. 1990. Effect of environment and seasonality on metal residue in tissue of wild and pond raised crayfish in south Louisiana. Arch. Environ. Toxicol. 19: 94.

Friberg, L. 1984. Cadmium and the kidney. Environ. Health Presp., 54: 1 -11.

Ibels, L., Pollock, C. 1986. Lead intoxication . Med. Toxicol. 1:387410. 
Im, J.Y., Paik, S.G., Han, P.L. 2006. Cadmium-induced astroglial death proceeds via glutathione depletion. J. Neurosci. Res., 83(2):301.

Jarup, L. 2003. Hazards of heavy metal contamination. British Medical Bulletin, 68:167 - 182

Jones, T.C., Hunt, R.D. 1983. Veterinary pathology. $5^{\text {th }}$ Ed. Lea and Febiger Philadelphia (USA).

Kikuchi, Y., Nomiyama, T., Kumagai, N.; Uemura, T., Omar, K. 2002. Cadmium concentration in current Japanese food beverages. J. Occupational Health. 44:240-247.

Levensen, H., Barnard, W.D. 1988. Wastes in Marine Environment. Hemisphere Publishing Corporation. Cambridge New York London. Chap. 6:123 136.

Manahan, S.E. 1992. Toxicological Chemistry, $2^{\text {nd }}$ Ed Lewis publishers. Inc. Boca Raon. Ann. Arbor, London, Tolyo.
Mert, W. 1987 Trace element in Human and Animal Nutrition. $5^{\text {th }}$ Ed. Vol. I and It London: Academic press.

Metin, S.I., Erkan, N.; Varlik, C.; Ozden, C.; Baygar, T., Kalafatoglu, H., Gun, H. 2000 Influence of modified atmosphere packaging on shelf life of fish-salami. Fleish Witchcraft Inc. $4: 49-51$.

Shibamoto, T., Bjeldanes, L.F. 1993. Introduction to food toxicology. Academic Press, Inc. Harcourt Brace and Company. New York. Food Science and Technology, International series.

Smith, R.P. 1992. A primer of environmental toxicology. Lea and Febiger, Philadelphia, U.S.A.

Sohsah - Madiha, A.M. 2009. Studies on some heavy metal residues in fresh water fish with special reference to water environmental pollution. $\mathrm{PhD}$, Thesis, (Meat Hygiene), Fac. Vet. Med., Benha Univ., Egypt. 